\title{
Hypercrosslinked organic polymer networks as potential adsorbents for pre-combustion $\mathrm{CO}_{2}$ capture
}

\author{
C. F. Martín' ${ }^{1}$, E. Stöckel ${ }^{2}$, R. Clowes ${ }^{3}$, D. J. Adams², A. I. Cooper ${ }^{2,3}$, J. J. Pis ${ }^{1}$, F. \\ Rubiera $^{1}$, C. Pevida ${ }^{1, *}$ \\ ${ }^{1}$ Instituto Nacional del Carbón (INCAR), CSIC. Apartado 73, 33080, Oviedo, Spain. \\ ${ }^{2}$ University of Liverpool, Robert Robinson Laboratories, Crown Street, Liverpool, L69 7ZD, \\ United Kingdom \\ ${ }^{3}$ Centre for Materials Discovery, Crown Street, Liverpool, L69 7ZD, United Kingdom \\ *corresponding author e-mail: cpevida@incar.csic.es (C. Pevida)
}

\begin{abstract}
Hypercrosslinked polymers (HCPs) synthesized by copolymerisation of $p$ dichloroxylene ( $p$-DCX) and 4-4'-bis (chloromethyl)-1-1'-biphenyl (BCMBP) constitute a family of low density porous materials with excellent textural development. Such polymers show microporosity and mesoporosity and exhibit Brunauer-Emmett-Teller (BET) surface areas of up to $1970 \mathrm{~m}^{2} \mathrm{~g}^{-1}$. The $\mathrm{CO}_{2}$ adsorption capacity of these polymers was evaluated using a thermogravimetric analyser (atmospheric pressure tests) and a high-pressure magnetic suspension balance (high pressure tests). $\mathrm{CO}_{2}$ capture capacities were related to the textural properties of the HCPs. The performance of these materials to adsorb $\mathrm{CO}_{2}$ at atmospheric pressure was characterized by maximum $\mathrm{CO}_{2}$ uptakes of $1.7 \mathrm{mmol} \mathrm{g}^{-1}(7.4 \mathrm{wt} \%$ ) at $298 \mathrm{~K}$. At higher pressures (30 bar), the polymers show $\mathrm{CO}_{2}$ uptakes of up to $13.4 \mathrm{mmol} \mathrm{g}^{-1}$ (59 wt \%), superior to zeolite-based materials (zeolite 13X, zeolite $\mathrm{NaX}$ ) and commercial activated carbons (BPL, Norit R). In addition, these polymers showed low isosteric heats of $\mathrm{CO}_{2}$ adsorption and good selectivity towards $\mathrm{CO}_{2}$. Hypercrosslinked polymers have potential to be applied as $\mathrm{CO}_{2}$ adsorbents in pre-combustion capture processes where high $\mathrm{CO}_{2}$ partial pressures are involved.
\end{abstract}

\section{Introduction}

Carbon Capture and Storage (CCS) technologies offer potential for diminishing $\mathrm{CO}_{2}$ emissions in the atmosphere. Adsorption is considered a promising technology for $\mathrm{CO}_{2}$ capture, offering possible energy savings compared to other more established 
absorption technologies ${ }^{1,2}$. Different types of solid sorbents have been investigated as potential adsorbents for $\mathrm{CO}_{2}$ capture. These include supported amines ${ }^{3-6}$, carbon-based sorbents $^{7-14}$, supported carbonates ${ }^{15,16}$ and zeolites ${ }^{17-19}$. Based on the nature of the bonding between the adsorbate molecule and the solid surface, adsorption can be categorized as either physical or chemical. Most adsorptive separation processes depend on physical adsorption rather than chemical adsorption. The requirement for adequate adsorptive capacity restricts the choice of adsorbent for practical separation processes to microporous adsorbents with pore diameters ranging from 2-3 nm. Previous studies have shown that only pores smaller than five times the molecular size of the adsorbate are effective for gas adsorption at atmospheric pressure. This observation was confirmed empirically ${ }^{20}$ as well as by mathematical simulation using grand canonical Monte Carlo (GCMC) and the nonlocal density functional theory (NLDFT) ${ }^{21}$. Since the molecular size of $\mathrm{CO}_{2}$ is $0.209 \mathrm{~nm}$, only pores less than $1.0 \mathrm{~nm}$ are effective towards $\mathrm{CO}_{2}$ capture at atmospheric pressure ${ }^{22}$. However, at higher pressures, $\mathrm{CO}_{2}$ is also adsorbed in the supermicroporosity range (pore sizes between 0.7 and $2 \mathrm{~nm})^{22}$.

The work presented here is based on the synthesis of solid adsorbents with the potential to be applied in pre-combustion $\mathrm{CO}_{2}$ capture -that is, the removal of $\mathrm{CO}_{2}$ from shifted-syngas prior to electricity generation with additional production of high-purity $\mathrm{H}_{2}$-. Solid sorbents are currently used in pressure swing adsorption (PSA) systems for the purification of hydrogen in petrochemical industries ${ }^{2,23,24}$. The synthesis gas or hydrogen is used as fuel or chemical raw material: for example, in liquid-fuel manufacturing or ammonia synthesis. The $\mathrm{CO}_{2}$ can also be used as a chemical raw material for dry ice manufacturing, carbonated beverage production ${ }^{25,} 26$, treatment of alkaline water, dry cleaning processes (supercritical $\left.\mathrm{CO}_{2}\right)^{27}$ or in enhanced oil recovery (EOR) from oil wells ${ }^{28}$.

Regarding PSA processes using solid sorbents, recent studies reveal the increased interest of this technology for pre-combustion $\mathrm{CO}_{2}$ capture applications, due to the reduced size of the capture system and the increased $\mathrm{CO}_{2}$ partial pressure when compared to post-combustion capture ${ }^{29,30}$.

There is currently significant interest in the use of porous networks for gas storage and trapping applications ${ }^{31-35}$. There are a few different classes of microporous organic polymers (MOPs) ${ }^{36}$ including hypercrosslinked polymers $(\mathrm{HCPs})^{37-41}$, polymers of intrinsic microporosity (PIMs) ${ }^{42,43}$, conjugated microporous polymers $(\mathrm{CMPs})^{44-47}$, 
and covalent organic frameworks $(\mathrm{COFs})^{32}$. MOPs can be classified as either amorphous (HCPs, PIMs, CMPs) or crystalline $(\mathrm{COFs})^{36}$. A possible advantage of MOPs, compared to other microporous materials such as MOFs, zeolites and activated carbons, is the potential synthetic diversity that can be incorporated into these organic structures $^{46}$.

HCPs represent a family of robust microporous organic materials that can exhibit high surface areas $37-39,41,48,49$. Unlike solution-processable PIMs, the permanent porosity in hypercrosslinked materials is a result of extensive crosslinking reactions which prevent the polymer chains from collapsing into a dense, non-porous state ${ }^{50,51}$. The most well-studied hypercrosslinked materials are "Davankov-type" resins $39,48,49$, prepared by post-crosslinking of polystyrenic networks. These materials can exhibit apparent BET surface areas as high as $2090 \mathrm{~m}^{2} \mathrm{~g}^{-1} 52$ and have been used as sorbents for organic vapours $^{53}$, for the recovery of organic compounds from water ${ }^{54}$, and in chromatography ${ }^{55}$. Among other features, the HCPs present robustness and scalability; these materials have good thermal stability, excellent chemical robustness (e.g., to strong acid and bases), and are quite readily produced on a large scale. In addition, they can be produced in a molded monolithic form. Another distinct advantage of the HCPs is their relative low heat of adsorption in comparison with other materials. We have recently reported the synthesis of HCPs by the self-condensation of bischloromethyl monomers such as dichloroxylene (DCX) and 4,4'-bis(chloromethyl)-1,1'-biphenyl $(\mathrm{BCMBP})^{40}$. These HCPs were predominantly microporous and exhibited BrunauerEmmett-Teller (BET) surface areas of up to $1904 \mathrm{~m}^{2} \mathrm{~g}^{-1}$. Networks based on BCMBP exhibited a gravimetric $\mathrm{H}_{2}$ storage capacity of $3.68 \mathrm{wt} \%$ at 15 bar and $77.3 \mathrm{~K}^{40}$. We were also able to carry out atomistic simulations of gas sorption in these networks ${ }^{56}$. In this work, HCPs networks have been evaluated for $\mathrm{CO}_{2}$ capture under either atmospheric (post-combustion capture conditions) and high pressure (pre-combustion capture conditions). The results indicate that HCPs can be considered as promising materials for the separation of $\mathrm{CO}_{2}$ under pre-combustion capture conditions. 


\section{Experimental}

\subsection{Chemicals}

Alpha-alpha'-dichloro-p-xylol (p-DCX, Aldrich, $98 \%$ ), 4,4'-bis(chloromethyl)1,1'-biphenyl (BCMBP, Aldrich, $95 \%$ ), and iron (III) chloride anhydrous ( $\mathrm{FeCl}_{3}, \mathrm{Alfa}$ Aesar- Johnson Matthey Company, $98 \%$,) were used as received. As solvents, dodecane (99\%), cyclohexane (99\%) and $n$-hexane $(99 \%)$ were purchased form Fischer Scientific. Dichloroethane (DCE, 99.8 \%, anhydr.) was purchased from Sigma Aldrich. All solvents were used as received.

2.2. General synthesis of HCPs (see Table 1 for $\% \mathrm{~mol} / \mathrm{mol}$ ratios for individual reactions)

To a solution of monomer(s) in anhydrous dichloroethane (DCE, $5 \mathrm{~mL}$ ), a slurry of $\mathrm{FeCl}_{3}(0.7 \mathrm{~g}, 4.3 \mathrm{mmol})$ in DCE $(5 \mathrm{~mL})$ was added under nitrogen atmosphere. The resulting mixture was heated while stirring at $353 \mathrm{~K}$ for $18 \mathrm{~h}$. The resulting brown precipitate was washed well with water and methanol until the filtrate became clear and then finally with diethyl ether. The polymer was dried under vacuum for $24 \mathrm{~h}$ at $333 \mathrm{~K}$.

Safety Note: Friedel-Crafts chemistry can be strongly exothermic and can lead to rapid temperature ramps. These reactions can generate very substantial pressures if carried out in sealed tubes.

\subsection{Characterization of the polymers}

The synthesized polymers were characterized in terms of texture and chemical composition. For the textural characterization, the specific surface areas and micropore volumes were determined from the $\mathrm{N}_{2}$ and $\mathrm{CO}_{2}$ adsorption isotherms at $77 \mathrm{~K}$ and $273 \mathrm{~K}$, respectively, measured in a Micromeritics ASAP 2420. Nitrogen surface areas were calculated by means of the BET equation and micropore volumes were determined from the Dubinin-Radushkevich (DR) equation applied to the $\mathrm{CO}_{2}$ and $\mathrm{N}_{2}$ adsorption isotherms $^{59}$. Helium densities at $308 \mathrm{~K}$ were measured in a Micromeritics Accupyc 1330 pycnometer. Prior to any measurement, the samples were degassed under vacuum at $373 \mathrm{~K}$ for approximately $10 \mathrm{~h}$.

Previous studies on the reproducibility of the synthesis of the HCPs (i.e., repeat reactions under the same conditions), showed some variation in both yield and surface 
area $^{40}$, possibly because of the propensity for these exothermic reactions to form "hot spots" and the general difficulty in controlling this on a small test scale ( $<2$ g solids). By contrast, the reproducibility of the gas sorption measurements was found to be excellent $( \pm 3 \%)$.

The chemical characterization involved microanalysis. Heats of $\mathrm{CO}_{2}$ adsorption were determined in the Micromeritics ASAP 2420 from the experimentally measured $\mathrm{CO}_{2}$ adsorption isotherms at 273 and $298 \mathrm{~K}$ up to a pressure of $1.13 \mathrm{bar}$.

\subsection{Assessment of the $\mathrm{CO}_{2}$ capture capacity}

The $\mathrm{CO}_{2}$ adsorption capacity of the samples at atmospheric pressure was evaluated in a thermogravimetric analyser (Setaram TGA). In a typical experiment, a sample ( $\sim 20 \mathrm{mg})$ was loaded in the TGA and dried at $373 \mathrm{~K}$ under inert atmosphere of argon $\left(50 \mathrm{~mL} \mathrm{~min}^{-1}\right)$ prior to the adsorption experiment. The system was then cooled to room temperature and, after stabilization of the sample mass and temperature (298 K), the Argon flow was changed to $\mathrm{CO}_{2}\left(50 \mathrm{~mL} \mathrm{~min}^{-1}\right)$. The $\mathrm{CO}_{2}$ adsorption capacity at $298 \mathrm{~K}$ was assessed from the maximum mass increase of the samples when exposed to a pure $\mathrm{CO}_{2}$ atmosphere.

The $\mathrm{CO}_{2}$ adsorption capacity at higher pressures was evaluated in a highpressure magnetic suspension balance (Rubotherm-VTI). Firstly, the samples were degassed at $373 \mathrm{~K}$ for $120 \mathrm{~min}$ under vacuum. Then, the system was cooled down to room temperature and sequentially pressurized (pressure steps $\sim 2.5$ bar) under $\mathrm{CO}_{2}$ atmosphere from 0.2 to 30 bar allowing to reach adsorption equilibrium. In this way, the $\mathrm{CO}_{2}$ adsorption isotherms at $298 \mathrm{~K}$ were determined. The $\mathrm{CO}_{2}$ uptake at each pressure was interpreted as the maximum $\mathrm{CO}_{2}$ adsorption capacity. In addition, $\mathrm{H}_{2}$ adsorption isotherms at $298 \mathrm{~K}$ up to a pressure of 40 bar were also determined following the same procedure.

The selectivity of the prepared HCPs to separate $\mathrm{CO}_{2}$ from $\mathrm{CO}_{2} / \mathrm{H}_{2}$ mixtures was estimated by the ratio between the $\mathrm{CO}_{2}$ and $\mathrm{H}_{2}$ adsorption capacities at a selected pressure. 


\section{Results and discussion}

\subsection{Chemical and textural characterization}

Following our previous report ${ }^{40}$, a series of HCPs was prepared via the selfcondensation of two bischloromethyl monomers, dichloroxylene (DCX) and 4,4'bis(chloromethyl)-1,1'-biphenyl (BCMBP) (Table 1 and Figure 1). Previous work was carried out using dichloroethane (DCE) as a suitable solvent. For optimisation purposes and to compare the previous synthesis with 'greener' systems, the synthesis of HCPs was also attempted in alternative solvents.

Table 1. Details on the synthesis of the series of hypercrosslinked polymers (monomer ratios given in $\% \mathrm{~mol} / \mathrm{mol}$ )

\begin{tabular}{cccccccccc}
\hline Sample & DCX & BCMBP & $\begin{array}{c}\mathrm{DCX} \\
(\mathrm{g})\end{array}$ & $\begin{array}{c}\mathrm{BCMBP} \\
(\mathrm{g})\end{array}$ & $\begin{array}{c}\mathrm{FeCl}{ }_{3} \\
(\mathrm{~g})\end{array}$ & $\begin{array}{c}\mathrm{DCE} \\
(\mathrm{mL})\end{array}$ & $\begin{array}{c}\text { Cyclo- } \\
\text { hexane } \\
(\mathrm{mL})\end{array}$ & $\begin{array}{c}\mathrm{n}- \\
\text { hexane } \\
(\mathrm{mL})\end{array}$ & $\begin{array}{c}\text { Dodecane } \\
(\mathrm{mL})\end{array}$ \\
\hline 1 & 0 & 100 & 0.00 & 1.069 & 0.696 & 10 & - & - & - \\
2 & 25 & 75 & 0.188 & 0.804 & 0.688 & 10 & - & - & \\
3 & 50 & 50 & 0.380 & 0.537 & 0.699 & 10 & - & - & - \\
4 & 75 & 25 & 0.570 & 0.269 & 0.704 & 10 & - & - & - \\
5 & 25 & 75 & 0.185 & 0.806 & 0.687 & - & 10 & - & - \\
6 & 25 & 75 & 0.187 & 0.806 & 0.708 & - & - & 10 & - \\
7 & 25 & 75 & 0.189 & 0.806 & 0.690 & - & - & - & 10 \\
\hline
\end{tabular}

a)

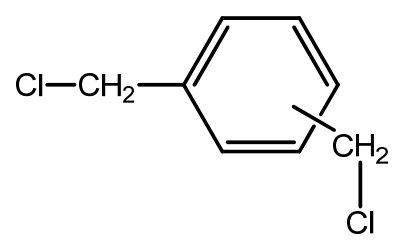

b)

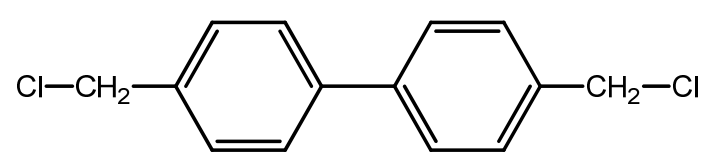

Figure 1. Monomers used for the synthesis of the hypercrosslinked polymer networks, a) DCX: alpha-alpha'-dichloro-p-xylene and b) BCMBP: 4,4'-bis(chloromethyl)-1,1'biphenyl. 
Microanalysis of the polymers is included in Table 2. The prepared HCPs contain mainly carbon (80-86 wt \%), the analysis being in agreement with the work carried out previously ${ }^{40}$. It can be observed that all samples have similar chemical compositions. We have previously demonstrated strong solvent effects for SonogashiraHagihara coupling based microporous materials ${ }^{57}$. This was ascribed to better monomer solubilities promoting reactivity. Presumably, networks with higher degrees of condensation are less able to collapse and densify, thus leading to higher levels of microporosity. It is likely that the same effects are being observed here. Indeed, the lower percentage of carbon found in 5-7 as compared to 1-4 (Table 2) as well as the lower $\mathrm{C} / \mathrm{H}$ ratio may be indicative of lower degrees of condensation and the presence of chlorine end groups. Additionally, the differences observed between 5-7 and 1-4 may be related to the solvation or lack of solvation by the different potentially porogenic solvents, as rationalized by Sherrington ${ }^{58}$.

Table 2. Chemical characteristics of HCPs

\begin{tabular}{ccc}
\hline \multirow{2}{*}{ Sample } & \multicolumn{2}{c}{ Ultimate microanalysis $(\mathrm{wt} \%, \mathrm{db})$} \\
\cline { 2 - 3 } & $\mathrm{C}$ & $\mathrm{H}$ \\
\hline 1 & 83.71 & 5.22 \\
2 & 86.28 & 5.27 \\
3 & 83.09 & 5.30 \\
4 & 81.56 & 5.34 \\
5 & 78.41 & 6.13 \\
6 & 80.96 & 5.29 \\
7 & 79.51 & 5.53 \\
\hline
\end{tabular}

Figures 2 and 3 show the $\mathrm{N}_{2}$ and $\mathrm{CO}_{2}$ adsorption isotherms at 77 and $273 \mathrm{~K}$, respectively, for the synthesized polymers. Table 3 summarizes the textural parameters calculated from these isotherms. BET surface areas $\left(S_{\mathrm{BET}}\right)$ were estimated in the relative pressure range between $0.00003-0.3$. Total pore volume $\left(V_{\mathrm{p}}\right)$ was evaluated using the Gurvitch's rule $\left(\mathrm{p} / \mathrm{p}^{0}=0.99\right)$. The mesopore volume $\left(V_{\text {meso }}\right)$ was calculated by the Hybrid Density Functional Theory (DFT), assuming cylindrical pores in pillared clay ${ }^{60}$, non-regularization and medium smoothing. Micropore volumes, $W_{0, \mathrm{~N} 2}$ (total micropore 
volume, estimated at relative pressures $<0.1$ ) and $W_{0, \mathrm{CO} 2}$ (narrow micropore volume, estimated at relative pressures $<0.01)$ were calculated by the DR equation ${ }^{59}$ applied to the $\mathrm{N}_{2}$ and $\mathrm{CO}_{2}$ adsorption isotherms (assuming affinity coefficients of 0.33 for $\mathrm{N}_{2}$ and 0.36 for $\mathrm{CO}_{2}$ ). Average widths of the narrow micropores, $L_{0, \mathrm{CO} 2}$, were estimated applying the Stoeckli-Ballerini relation to the $\mathrm{CO}_{2}$ adsorption isotherms ${ }^{61}$.

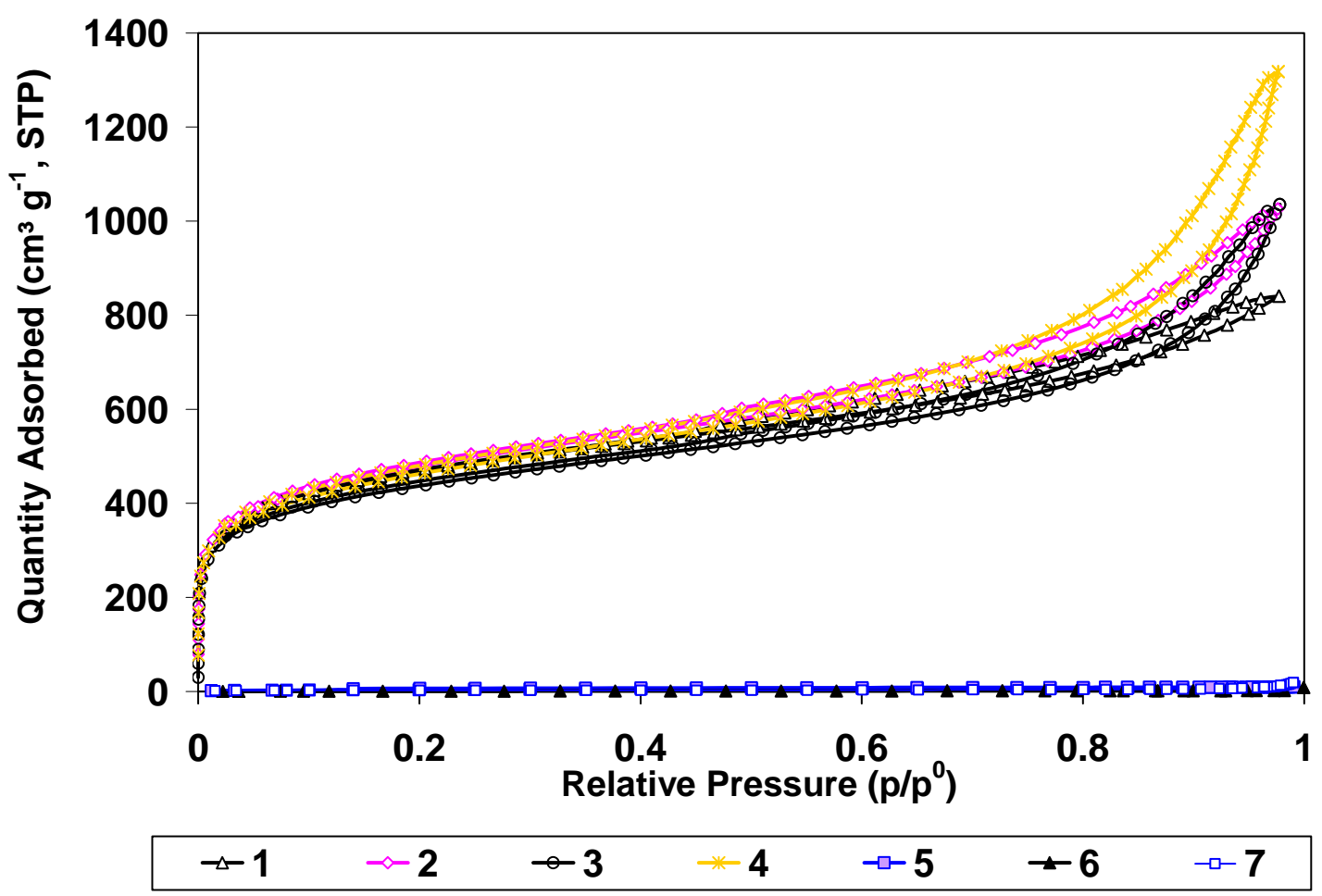

Figure 2. $\mathrm{N}_{2}$ adsorption isotherms at $77 \mathrm{~K}$ for $\mathrm{HCPs}$

Polymers 1 to 4 showed type IV $\mathrm{N}_{2}$ adsorption isotherms, according to the BDDT classification ${ }^{62}$, characterized by the presence of a hysteresis loop at relative pressures above 0.4 . This suggests the presence of significant mesoporosity besides microporosity. Great similarities in $\mathrm{N}_{2}$ adsorption up to relative pressures around 0.4 were observed. However, hysteresis loops at higher relative pressures show differences and so does the mesoporosity in the samples. Samples 5, 6 and 7 showed negligible $\mathrm{N}_{2}$ adsorption. Polymer 4 showed the greatest $\mathrm{N}_{2}$ uptake. 


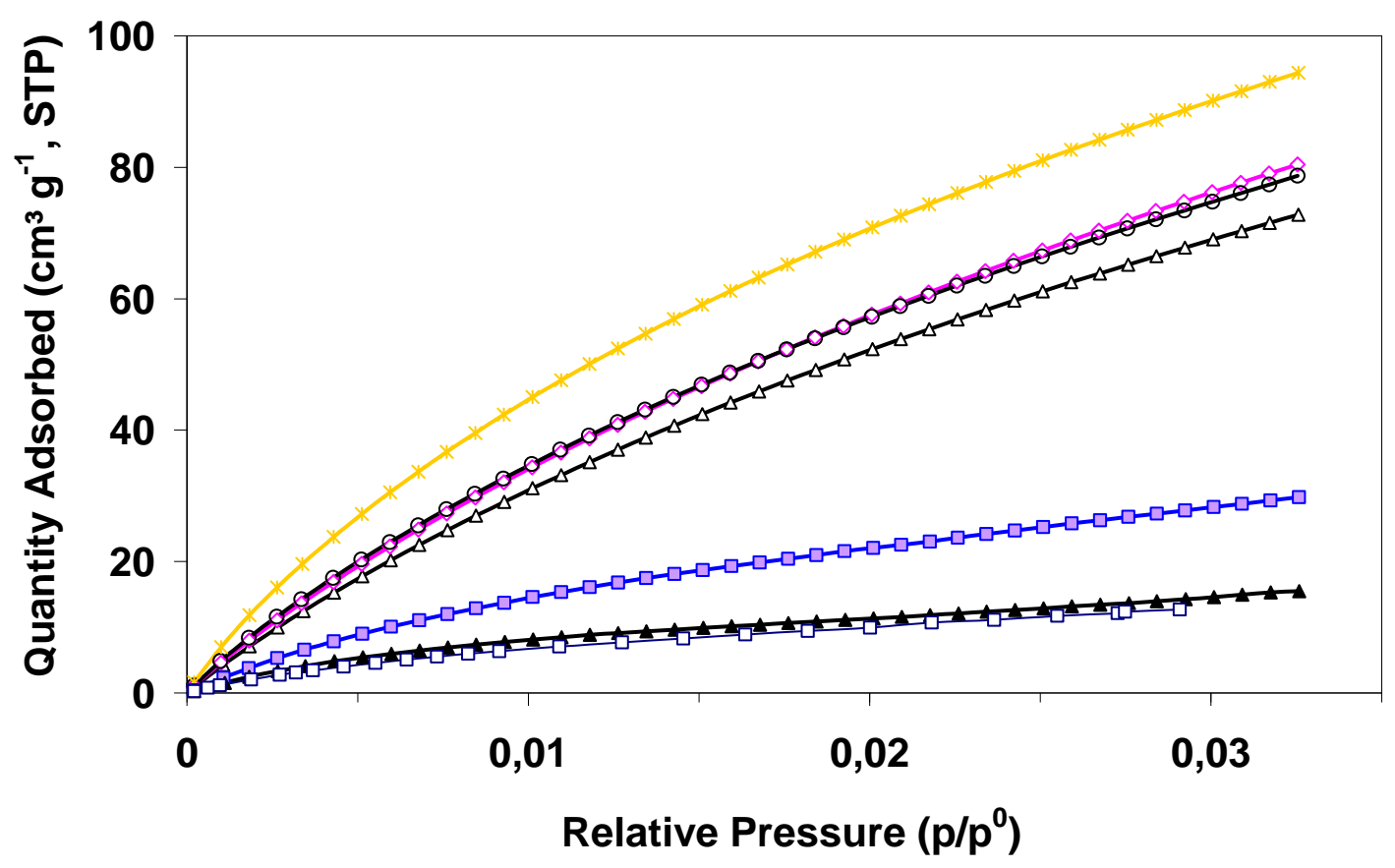

$\neg-\quad \neg 2 \quad \neg 3 \quad-4 \quad \neg-5 \quad \neg 6 \quad-\square 7$

Figure 3. $\mathrm{CO}_{2}$ adsorption isotherms at $273 \mathrm{~K}$ for HCPs.

Figure 3 shows the $\mathrm{CO}_{2}$ adsorption isotherms at $273 \mathrm{~K}$ for HCPs (1 to 7). Subatmospheric $\mathrm{CO}_{2}$ adsorption isotherms at $273 \mathrm{~K}$ allow the evaluation of microporosity with pore sizes of less than $1 \mathrm{~nm}$. Differences in the volumes of $\mathrm{CO}_{2}$ adsorbed and the shape of the isotherms can be observed. Polymers 5, 6 and 7 showed little adsorption of $\mathrm{CO}_{2}$ with curved isotherms that suggest the presence of narrow micropore distributions. Samples 1 to 4 presented similar $\mathrm{CO}_{2}$ isotherms characterized by rectilinear shape that indicates the presence of wider micropores. The highest $\mathrm{CO}_{2}$ uptake corresponded to sample 4.

The textural parameters calculated from the $\mathrm{N}_{2}$ and $\mathrm{CO}_{2}$ adsorption isotherms are summarized in Table 3. The absolute densities measured at $308 \mathrm{~K}$ for all HCPs were recorded to be around $1 \mathrm{~g} \mathrm{~cm}^{-3}$. The HCPs synthesized using cyclohexane, $\mathrm{n}$-hexane and dodecane as solvents (polymers 5,6 and 7) showed negligible total pore volume and BET surface areas. Polymers 1 to 4 , synthesized with DCE, showed $S_{\text {BET }}$ values around $1600 \mathrm{~m}^{2} \mathrm{~g}^{-1}$, slightly lower than the previous reported ${ }^{40}$, and micropore volumes, $\mathrm{W}_{0, \mathrm{~N} 2}$, around $0.6 \mathrm{~cm}^{3} \mathrm{~g}^{-1}$. Mesoporosity in these polymers showed more dispersion with mesopore volumes ranging from 0.3 to $0.5 \mathrm{~cm}^{3} \mathrm{~g}^{-1}$. Polymer 4 exhibited the lowest mesopore volume but the greatest total pore volume. 
Regarding the evaluation of narrow microporosity it can be observed in Table 3 that values around $0.3 \mathrm{~cm}^{3} \mathrm{~g}^{-1}$ and $0.9 \mathrm{~nm}$ for the narrow micropore volume, $W_{0, \mathrm{CO} 2}$, and average narrow micropore width, $L_{0, \mathrm{CO} 2}$, respectively, were obtained. From these results, it can be concluded that replacement of DCE by alkane solvents in the HCP synthesis does not enhance the textural development. However, the ratio DCX/BCMBP during the synthesis may influence the development of mesoporosity in the polymers.

Table 3. Absolute density, $\rho_{\mathrm{He}}$, and textural parameters calculated from the $\mathrm{N}_{2}$ and $\mathrm{CO}_{2}$ adsorption isotherms at 77 and $273 \mathrm{~K}$, respectively

\begin{tabular}{|c|c|c|c|c|c|c|c|}
\hline \multirow{2}{*}{ Sample } & \multirow{2}{*}{$\rho_{\mathrm{He}}$} & \multicolumn{4}{|c|}{$\mathrm{N}_{2}$ adsorption at $77 \mathrm{~K}$} & \multicolumn{2}{|c|}{$\mathrm{CO}_{2}$ adsorption at $273 \mathrm{~K}$} \\
\hline & & $S_{\mathrm{BET}}$ & $V_{p}$ & $V_{\text {meso }}$ & $W_{0, \mathrm{~N} 2}$ & $W_{0, \mathrm{CO} 2}$ & $L_{0, \mathrm{CO} 2}$ \\
\hline 1 & 1.04 & 1646 & 1.26 & 0.51 & 0.66 & 0.27 & 0.9 \\
\hline 2 & 0.93 & 1684 & 1.47 & 0.50 & 0.64 & 0.29 & 0.9 \\
\hline 3 & 1.03 & 1531 & 1.44 & 0.40 & 0.60 & 0.28 & 0.9 \\
\hline 4 & 1.09 & 1642 & 1.74 & 0.33 & 0.59 & 0.31 & 0.8 \\
\hline 5 & 0.93 & 13 & 0.02 & - & - & 0.13 & 0.9 \\
\hline 6 & 1.09 & 3 & 0.01 & - & - & 0.06 & 0.8 \\
\hline 7 & 1.13 & 9 & 0.02 & - & - & 0.05 & 0.8 \\
\hline
\end{tabular}

$\rho_{\mathrm{He}}\left(\mathrm{g} \mathrm{cm}^{-3}\right)$ : Helium density; $S_{\mathrm{BET}}\left(\mathrm{m}^{2} \mathrm{~g}^{-1}\right)$ : Brunauer Emmet and Teller surface area; $V_{\mathrm{p}}\left(\mathrm{cm}^{3} \mathrm{~g}^{-1}\right)$ : total pore volumen; $V_{\text {meso }}\left(\mathrm{cm}^{3} \mathrm{~g}^{-1}\right)$ : mesopore volume (Hybrid DFT); $W_{0, \mathrm{~N} 2}\left(\mathrm{~cm}^{3} \mathrm{~g}^{-1}\right)$ : total micropore volume at $\mathrm{p} / \mathrm{p}^{0}<0.1$ (DR equation); $W_{0, \mathrm{co} 2}\left(\mathrm{~cm}^{3} \mathrm{~g}^{-1}\right)$ : narrow micropore volume at $\mathrm{p} / \mathrm{p}^{0}<0.01$ (DR equation); $L_{0, \mathrm{CO} 2}(\mathrm{~nm})$ : average narrow micropore width (Stoeckli-Ballerini relation).

Figure 4 shows the pore size distribution assessed by the Hybrid DFT method, assuming a model of cylindrical pores in pillared clay. In general, polymers presented here showed pore size distributions with maxima centered in the supermicroporosity range $(2 \mathrm{~nm}>$ micropore width $>0.7 \mathrm{~nm})$, in agreement with the average micropore widths (0.8-0.9 nm) determined from the Stoeckli-Ballerini relation (see Table 3). 


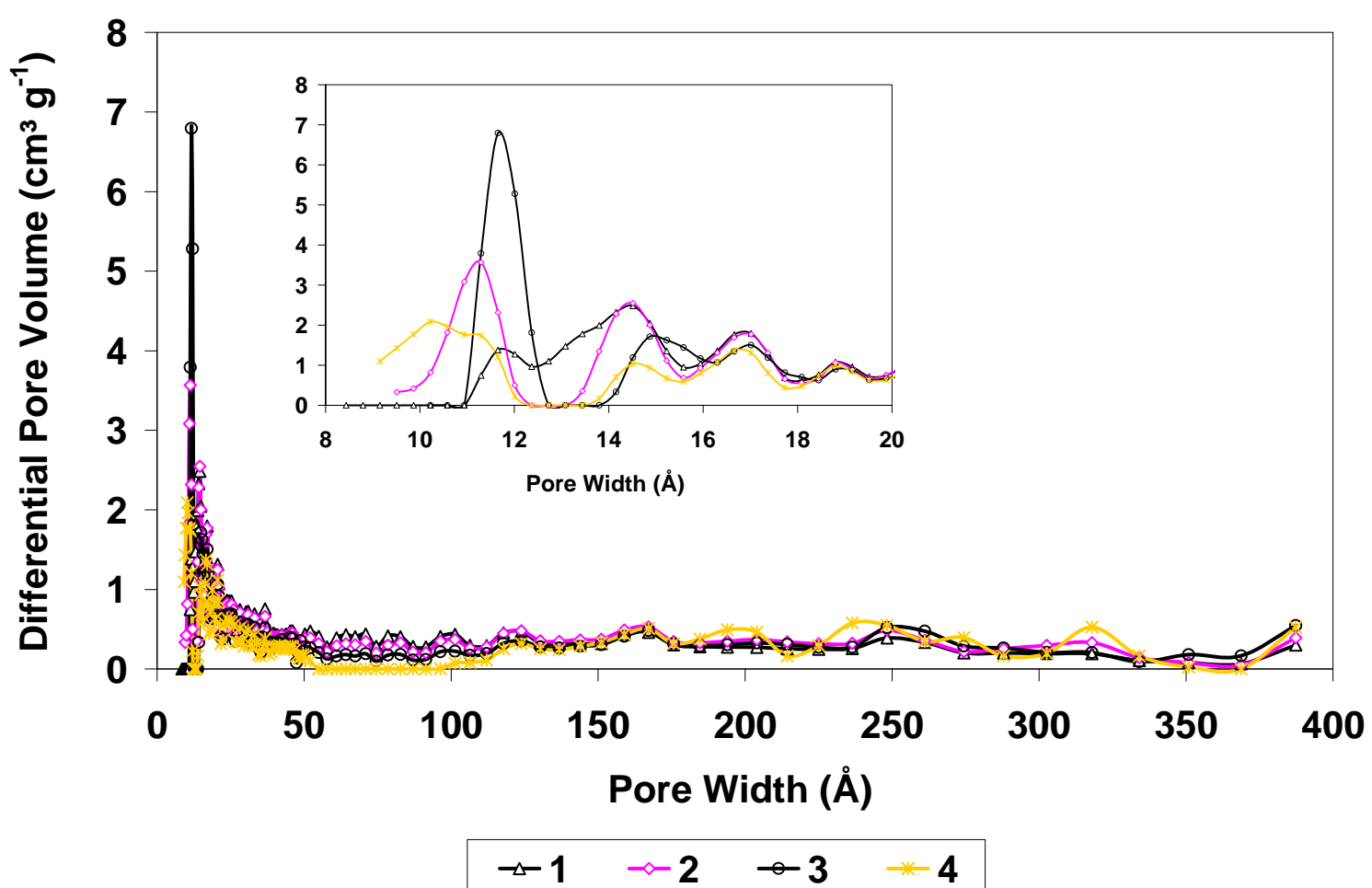

Figure 4. Pore size distributions for HCPs (inset shows the detail of the micropore region).

\subsection{Isosteric heat of adsorption of $\mathrm{CO}_{2}$}

The isosteric heat of adsorption $\left(Q_{\mathrm{st}}\right)$, which is defined as the difference in the partial molar enthalpy of the adsorbate between the gas phase and the adsorbed phase, represents the strength of the adsorbate-adsorbent interactions. Quantification of $Q_{\mathrm{st}}$ is very important for the design of adsorption processes because the heat released upon adsorption is partially adsorbed on the sorbent which causes a rise in the sorbent temperature and thus influences the local adsorption equilibrium and kinetics and, as a result, the overall gas separation efficiency ${ }^{63}$. Adsorption isotherms of $\mathrm{CO}_{2}$ were obtained at different temperatures, $273 \mathrm{~K}$ and $298 \mathrm{~K}$, and were used for the calculation of the isosteric heat of adsorption, based on the Clausius-Clapeyron equation ${ }^{64}$. The isosteric heats of adsorption are plotted in Figure 5 as a function of the amount of $\mathrm{CO}_{2}$ adsorbed. 


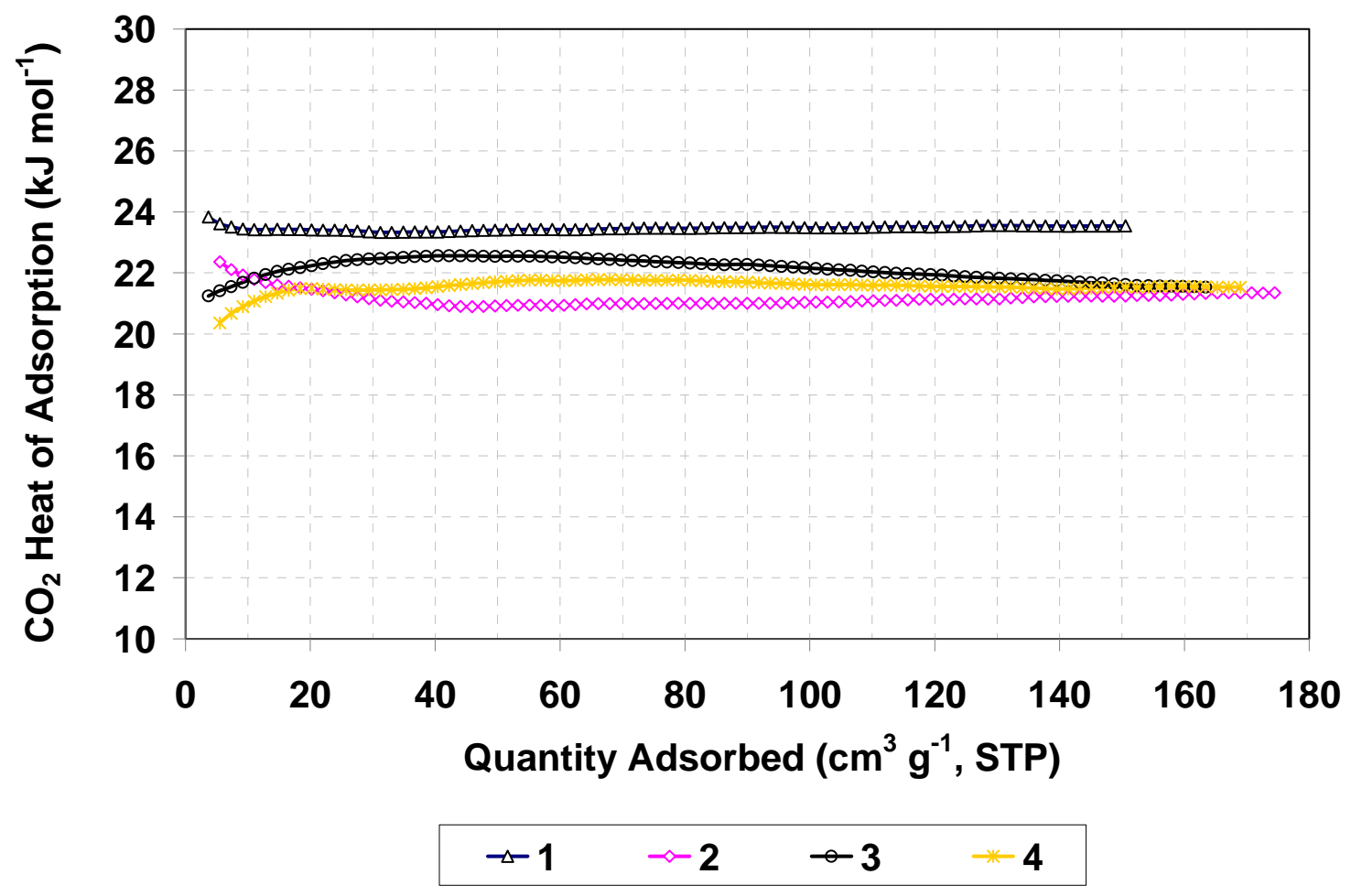

Figure 5. Heats of adsorption of $\mathrm{CO}_{2}$ for $\mathrm{HCPs}$.

In Figure 5 it can be observed that at lower loadings $\left(<20 \mathrm{~cm}^{3} \mathrm{~g}^{-1}\right.$, STP $)$ the performance of the samples differs and the heats of adsorption can slightly increase (polymers 3 and 4), decrease (polymer 2) or stay constant (polymer 1). This behaviour may be assigned to uncertainties in the evaluation procedure because at very low pressures, the isotherm measurements at lower temperatures may not be precise for strongly adsorbed gases ${ }^{65}$. However, at higher loadings the heats of adsorption of $\mathrm{CO}_{2}$ reach nearly constant values with loading, of approximately $21 \mathrm{~kJ} \mathrm{~mol}^{-1}$ for polymers 2 , 3 and 4 and $23.5 \mathrm{~kJ} \mathrm{~mol}^{-1}$ for polymer 1 . Generally, these results indicate an energetically homogeneous surface of the polymers.

Other nanoporous materials like MIF (aluminum-free ZSM-5 type zeolite), IRMOFs (isoreticular MOFs) and SWNT (single-wall carbon nanotubes) present heterogeneous surfaces so there exist significant differences in the heat of $\mathrm{CO}_{2}$ adsorption at low and high loadings ${ }^{66}$. For MOFs with BET surface areas ranging from 1200 to $1600 \mathrm{~m}^{2} \mathrm{~g}^{-1}$ - that is, similar $S_{\mathrm{BET}}$ values to those reported here - higher heats of adsorption for $\mathrm{CO}_{2}$ at low coverage were reported $\left(\sim 35 \mathrm{~kJ} \mathrm{~mol}^{-1}\right)^{67}$. These were found to decrease to approximately $25 \mathrm{~kJ} \mathrm{~mol}^{-1}$ at higher gas loadings. Significant increases in 
the isosteric heat were observed for the adsorption of $\mathrm{CO}_{2}$ in amine-grafted MOFs, particularly at very low loadings; a maximum value of $Q_{\mathrm{st}}$ of $90 \mathrm{~kJ} \mathrm{~mol}^{-1}$ was observed, indicating a strong and selective interaction of $\mathrm{CO}_{2}$ with the amine functionalities ${ }^{68}$. This value compares well with previously reported data obtained for aminefunctionalized silicas $\left(100 \mathrm{~kJ} \mathrm{~mol}^{-1}\right)^{69}$. High enthalpies at zero coverage were also observed for cation-exchanged zeolites such as $\mathrm{NaX}\left(49 \mathrm{~kJ} \mathrm{~mol}^{-1}\right)$ and Na-ZSM-5 $\left(50 \mathrm{~kJ} \mathrm{~mol}^{-1}\right)$ that decrease with coverage to a plateau around $30 \mathrm{~kJ} \mathrm{~mol}^{-1} 64$.

Isosteric heats of $\mathrm{CO}_{2}$ adsorption for these HCPs are similar to those obtained for activated carbons which have $Q_{\mathrm{st}}$ values of approximately $20.3 \mathrm{~kJ} \mathrm{~mol}^{-1}{ }^{70}$, reflecting the structural similarities between the two kinds of carbonaceous materials. Multi-wall carbon nanotubes (CNT) and amine-grafted $\mathrm{CNT}$ present average heats of $\mathrm{CO}_{2}$ adsorption around $11.8 \mathrm{~kJ} \mathrm{~mol}^{-1}$ and $18.9 \mathrm{~kJ} \mathrm{~mol}^{-1}{ }^{71}$, respectively, lower than those assessed for HCPs and many kinds of zeolites ${ }^{72}$.

\section{3. $\mathrm{CO}_{2}$ capture capacity}

$\mathrm{CO}_{2}$ capture capacities of the prepared HCPs were evaluated at atmospheric and high pressures (up to 30 bar) at room temperature (298 K).

\subsubsection{Atmospheric pressure tests}

Figure 6 shows the mass uptake of the samples during tests conducted on the TGA under a $\mathrm{CO}_{2}$ flow $\left(50 \mathrm{~mL} \mathrm{~min}{ }^{-1}\right) . \mathrm{CO}_{2}$ uptakes are expressed in terms of mass of $\mathrm{CO}_{2}$ per mass of dry adsorbent. The HCPs show a $\mathrm{CO}_{2}$ capture capacity of approximately $7 \mathrm{wt} \%$. Due to their low textural development, the poorest performance corresponded to samples 5, 6 and 7 with $\mathrm{CO}_{2}$ uptakes that do not exceed $2.5 \mathrm{wt} \%(0.6$ $\mathrm{mmol} \mathrm{g} \mathrm{g}^{-1}$ ). 


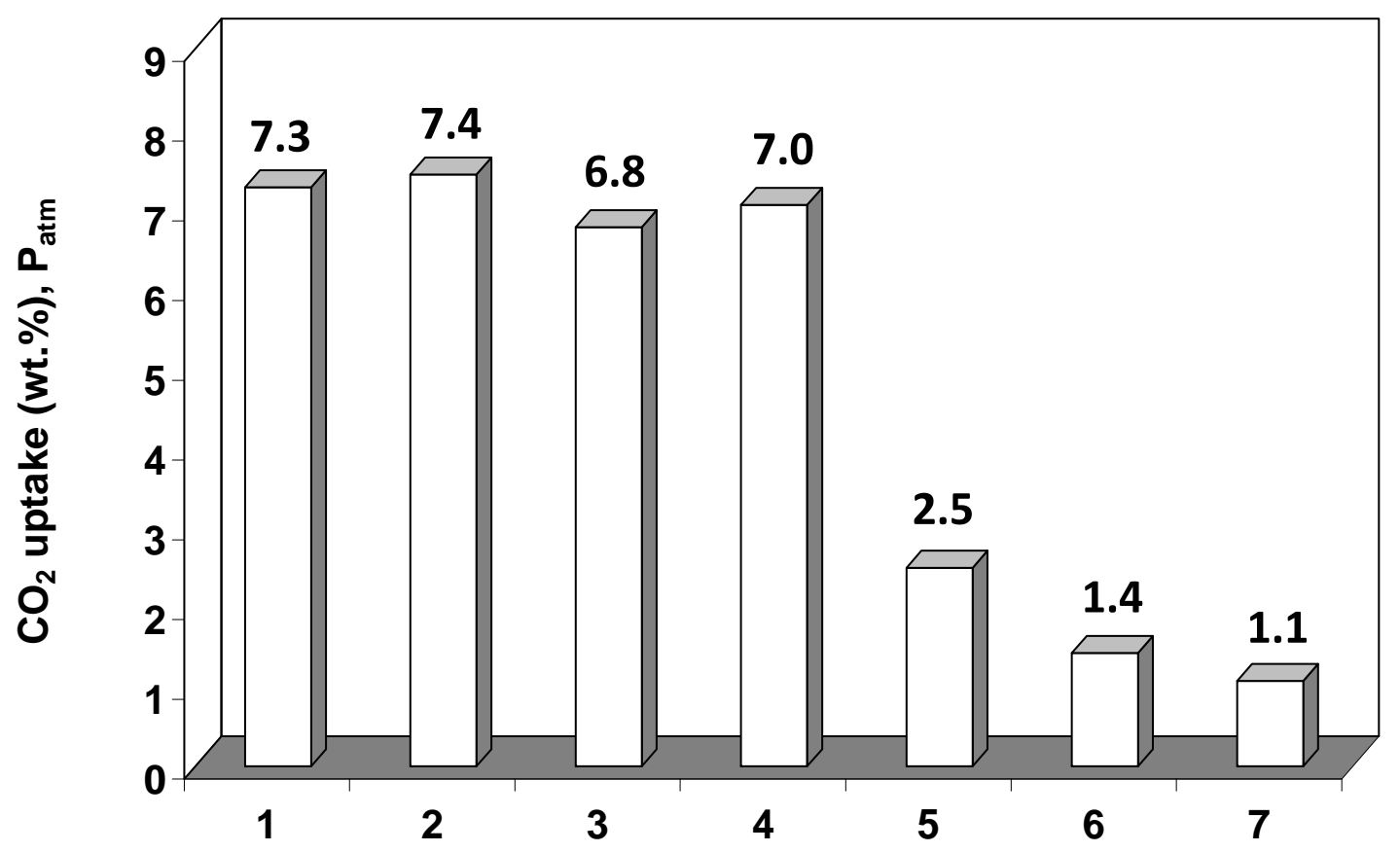

Figure 6. $\mathrm{CO}_{2}$ uptakes of the HCPs evaluated at atmospheric pressure and $298 \mathrm{~K}$.

Figure 7 shows that $\mathrm{CO}_{2}$ uptakes at atmospheric pressure and ambient temperature seem to correlate better with narrow micropore volumes, $W_{0, \mathrm{CO} 2}$, than with total micropore volumes, $W_{0 \mathrm{~N} 2}$. Microporous activated carbons from phenolformaldehyde resins ${ }^{73}$ have also been included in Figure 7 to validate the correlation. HCPs fall below the fitted line in Figure 7b, suggesting that experimental $\mathrm{CO}_{2}$ capture capacities are lower than could be theoretically expected, according to their narrow micropore volume. $\mathrm{CO}_{2}$ adsorption at atmospheric pressure is sensitive to the micropore width $^{20,21}$ and it has been demonstrated for activated carbons that micropore widths lower than $0.7 \mathrm{~nm}$ are the most active towards $\mathrm{CO}_{2}$ capture at atmospheric pressure ${ }^{73}$. Thus, the presence of supermicropores $(2 \mathrm{~nm}>$ micropore width $>0.7 \mathrm{~nm})$ in these samples could account for the deviation from the fitted line (Figure $7 \mathrm{~b}$ ). 
a)

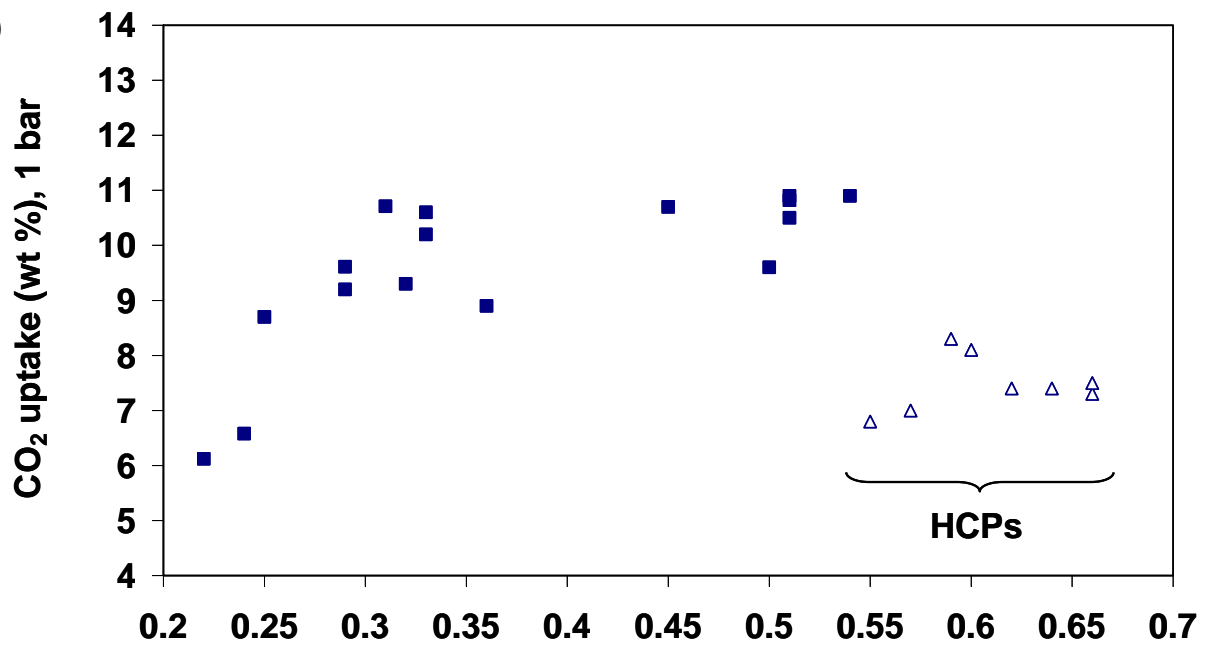

b)

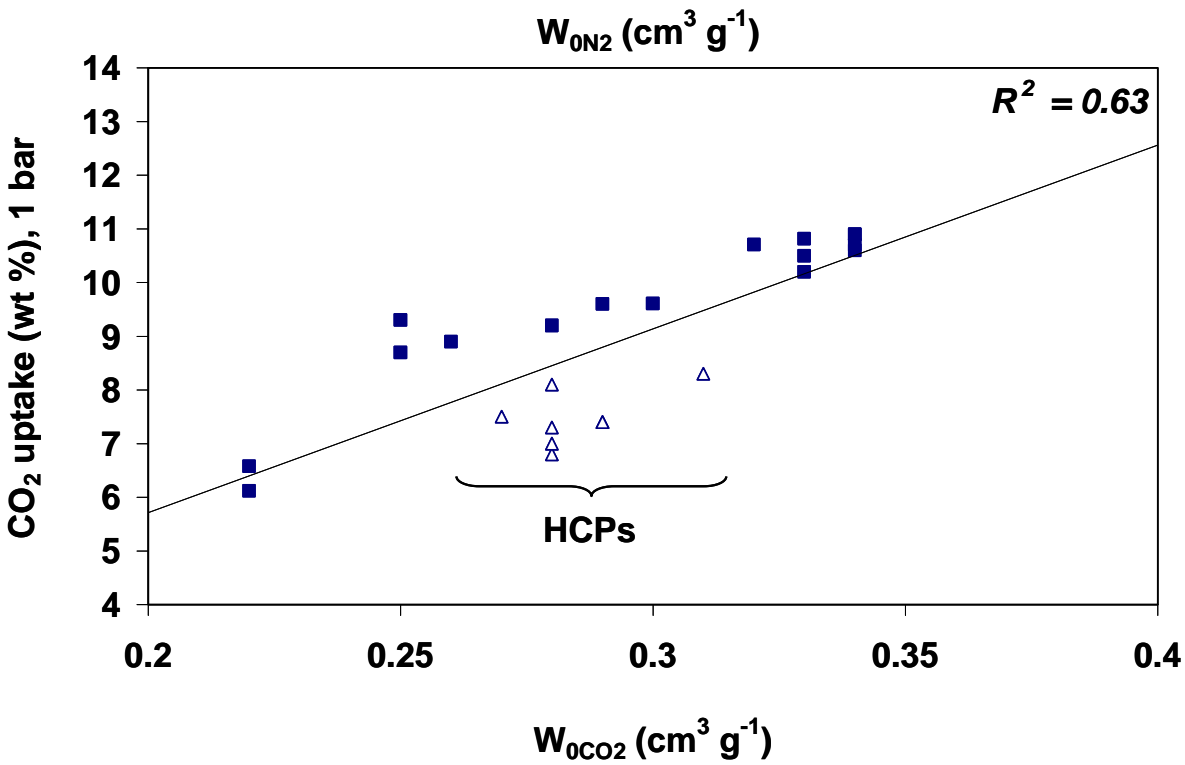

Figure 7. Correlation of the $\mathrm{CO}_{2}$ uptake at 1 bar with textural parameters (triangles: HCPs, squares: carbon-based adsorbents ${ }^{73}$, a) total micropore volume, $W_{0, \mathrm{~N} 2}$ and $b$ ) narrow micropore volume, $W_{0, \mathrm{CO} 2}$.

\subsubsection{High pressure tests}

Figure 8 presents the $\mathrm{CO}_{2}$ and $\mathrm{H}_{2}$ uptakes of some of the HCPs at 30 bar and $298 \mathrm{~K}$. These values were obtained from the corresponding adsorption isotherms at $298 \mathrm{~K}$. For polymers 1 to 4 the $\mathrm{CO}_{2}$ adsorption capacity at 30 bar is significantly greater (by nearly two orders of magnitude) than the $\mathrm{H}_{2}$ uptake. The highest value corresponded to polymer 1 with 0.1 wt. $\% \mathrm{H}_{2}$ uptake; for the rest of the samples the values were 
insignificant in comparison with the $\mathrm{CO}_{2}$ uptake. Therefore, the polymers may be selective to the separation of $\mathrm{CO}_{2}$ from $\mathrm{CO}_{2} / \mathrm{H}_{2}$ mixtures (pre-combustion conditions). All tested polymers present significant $\mathrm{CO}_{2}$ adsorption at 30 bar reaching values of approximately $50 \mathrm{wt} \%$. The maximum $\mathrm{CO}_{2}$ uptake corresponded to sample 1 that reached $59 \mathrm{wt} \%\left(13.4 \mathrm{mmol} \mathrm{g}^{-1}\right)$. This polymer also exhibited the highest heat of $\mathrm{CO}_{2}$ adsorption (see Figure 5).

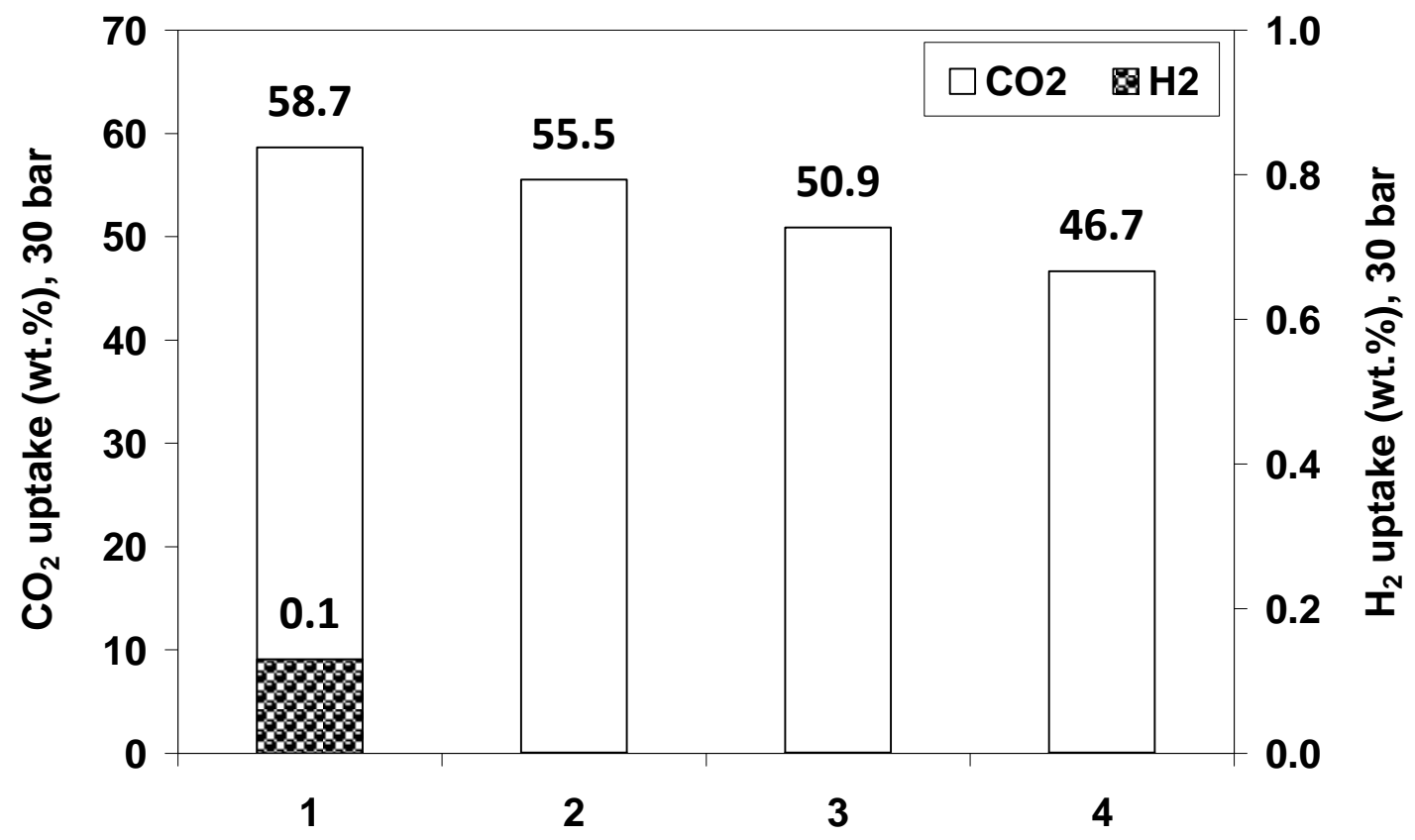

Figure 8. $\mathrm{CO}_{2}$ and $\mathrm{H}_{2}$ uptakes of the HCPs evaluated at 30 bar and $298 \mathrm{~K}$.

As for the atmospheric pressure tests, the $\mathrm{CO}_{2}$ uptakes at 30 bar were related to the textural parameters of the polymers (Figure 9). Contrary to the observed trend in the atmospheric pressure $\mathrm{CO}_{2}$ capture tests, a good linear correlation exists between high pressure $\mathrm{CO}_{2}$ uptakes and total micropore volume, $W_{0, \mathrm{~N} 2}$, of the polymers. Thus, $\mathrm{CO}_{2}$ uptake at high pressure seems to depend on the total micropore volume, independently of the micropore size.

At atmosperic pressure the narrow micropore volume (pore sizes below $0.6 \mathrm{~nm}$ ), evaluated by the $\mathrm{CO}_{2}$ adsorption isotherm at $273 \mathrm{~K}$, determines the maximum $\mathrm{CO}_{2}$ uptake. This is not surprising since, as a consequence of the relatively high saturation pressure of $\mathrm{CO}_{2}$, the process of $\mathrm{CO}_{2}$ capture at low pressures corresponds to a small degree of pore filling which involves, exclusively, the narrower micropores in the 
carbons. At high pressure (30 bar) the total micropore volume, determined by the $\mathrm{N}_{2}$ adsorption isotherm at $77 \mathrm{~K}$, is the textural parameter more directly related to the $\mathrm{CO}_{2}$ capacity of the materials. The good agreement revealed by Fig. 9a indicates that the retention of $\mathrm{CO}_{2}$ under pre-combustion conditions (high pressures) occurs by filling of the entire microporosity. This is not accidental, because under such experimental conditions (298K and 30 bar), $\mathrm{CO}_{2}$ adsorption is close to saturation.

a)

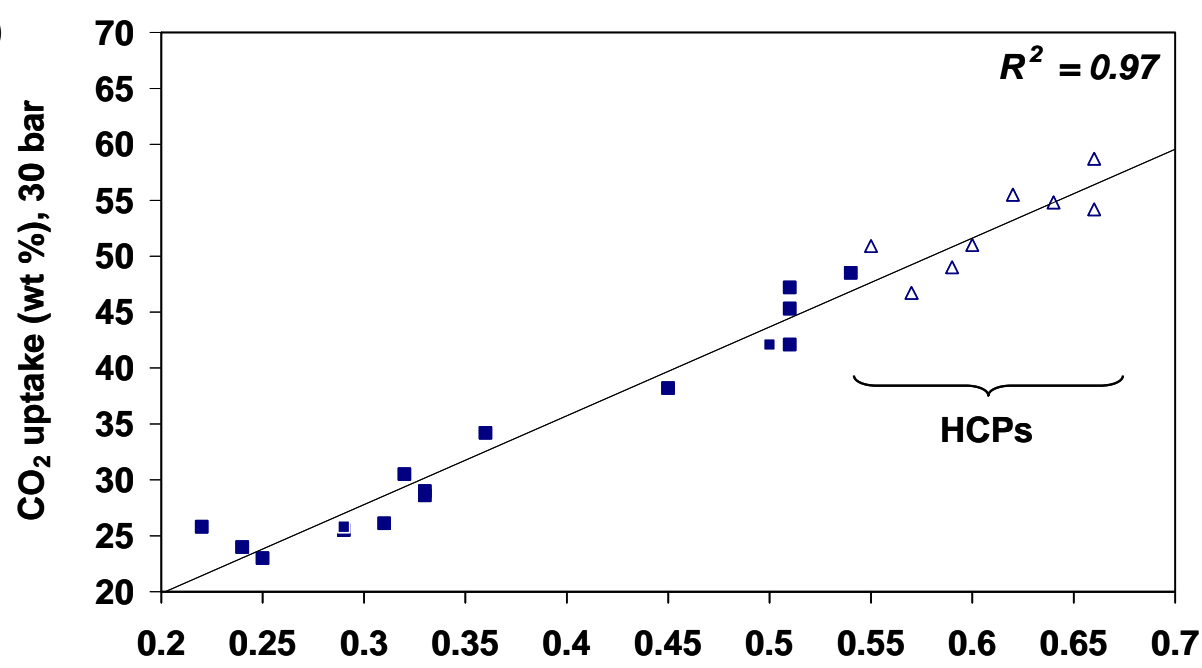

b)

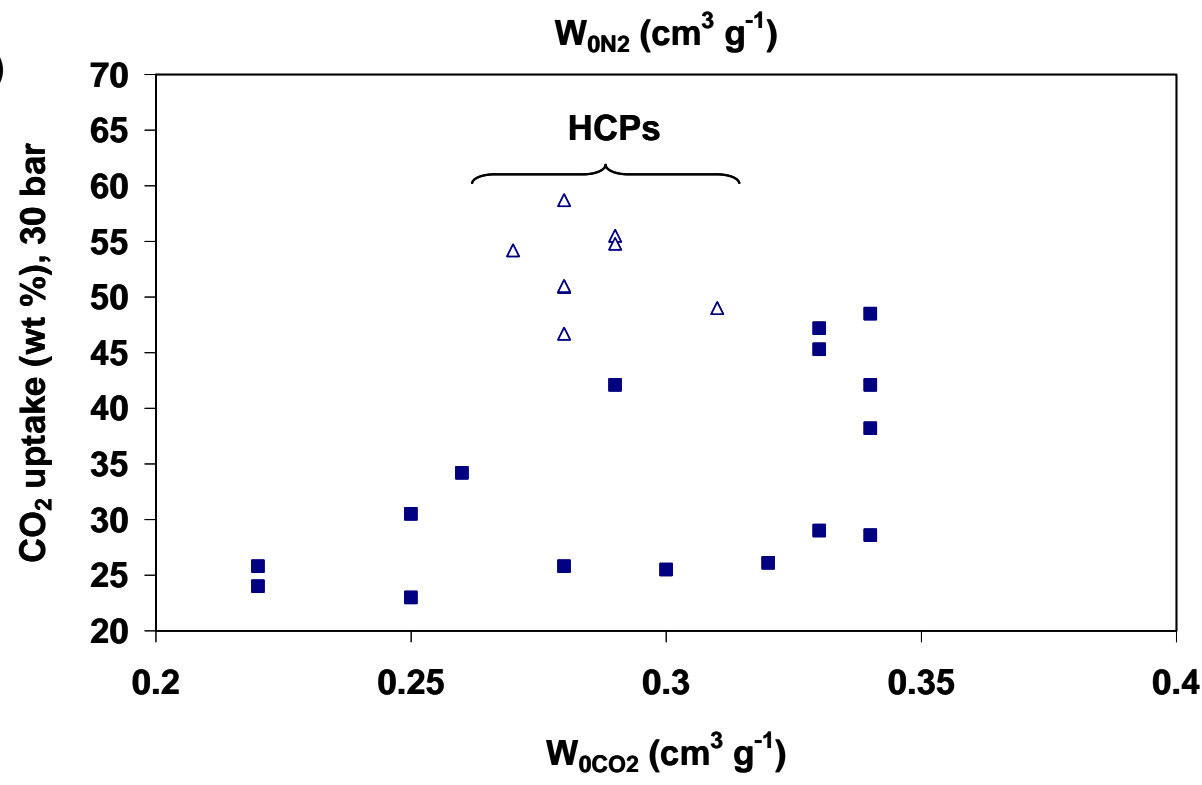

Figure 9. Correlation of the $\mathrm{CO}_{2}$ uptake at 30 bar with textural parameters (triangles: HCPs, squares: carbon-based adsorbents ${ }^{73}$, a) total micropore volume, $W_{0, \mathrm{~N} 2}$ and b) narrow micropore volume, $W_{0, \mathrm{CO} 2}$. 
In Table 4, the $\mathrm{CO}_{2}$ uptakes of the HCPs polymers prepared in this work are compared with other $\mathrm{CO}_{2}$ adsorbents that have shown promising performance. Most of the current literature on $\mathrm{CO}_{2}$ physisorbents is based on zeolite-like materials and MOFs. The wide range of experimental conditions used to evaluate the $\mathrm{CO}_{2}$ uptakes makes it difficult to make precise comparisons between different physisorbents. The selection of $\mathrm{CO}_{2}$ adsorbents for particular applications is governed by the process design and desired process performance.

Table 4. $\mathrm{CO}_{2}$ capture performance of adsorbent materials.

\begin{tabular}{|c|c|c|c|c|}
\hline Materials & $\begin{array}{c}\mathrm{CO}_{2} \text { Heat of } \\
\text { Adsorption } \\
\left(\mathrm{kJ} \mathrm{mol}^{-1}\right)\end{array}$ & $\begin{array}{c}\mathrm{CO}_{2} \text { adsorption } \\
\text { capacity }\left(\mathrm{mmol} \mathrm{g}^{-1}\right)\end{array}$ & $\begin{array}{l}\text { Conditions } \\
(\mathrm{P}, \mathrm{T})\end{array}$ & References \\
\hline \multirow{2}{*}{ HCP 1} & \multirow{2}{*}{23.5} & 1.7 & 1 bar, $298 \mathrm{~K}$ & \multirow{2}{*}{ this work } \\
\hline & & 13.3 & 30 bar, $298 \mathrm{~K}$ & \\
\hline \multirow{2}{*}{ HCP 2} & \multirow{2}{*}{21.2} & 1.7 & 1 bar, $298 \mathrm{~K}$ & \multirow{2}{*}{ this work } \\
\hline & & 12.6 & 30 bar, $298 \mathrm{~K}$ & \\
\hline \multirow{2}{*}{ HCP 3} & \multirow{2}{*}{22.1} & 1.6 & 1 bar, $298 \mathrm{~K}$ & \multirow{2}{*}{ this work } \\
\hline & & 11.6 & 30 bar, $298 \mathrm{~K}$ & \\
\hline \multirow{2}{*}{$\mathrm{HCP} 4$} & \multirow{2}{*}{21.6} & 1.6 & 1 bar, $298 \mathrm{~K}$ & \multirow{2}{*}{ this work } \\
\hline & & 10.6 & 30 bar, $298 \mathrm{~K}$ & \\
\hline \multirow{2}{*}{$\mathrm{Ni}_{2}(\mathrm{BDC})_{2} \mathrm{Dabco}^{\mathrm{a}}$} & \multirow{2}{*}{20.4} & 12.5 & 15 bar, $298 \mathrm{~K}$ & \multirow{2}{*}{$\begin{array}{l}74 \\
75\end{array}$} \\
\hline & & 14.8 & 24 bar, $298 \mathrm{~K}$ & \\
\hline \multirow{2}{*}{$\mathrm{Zn}_{2}(\mathrm{BDC})_{2} \mathrm{Dabco}^{\mathrm{a}}$} & \multirow{2}{*}{21.6} & 2.1 & 1 bar, $298 \mathrm{~K}$ & \multirow{2}{*}{$\begin{array}{l}74 \\
74\end{array}$} \\
\hline & & 13.7 & 15 bar, $298 \mathrm{~K}$ & \\
\hline ZIF-70 & - & 2.2 & 1 bar, $298 \mathrm{~K}$ & 67 \\
\hline USO-2-Ni & - & 13.6 & 25 bar, $298 \mathrm{~K}$ & 75 \\
\hline USO-2-Ni-A ${ }^{b}$ & - & 3.2 & 1 bar, $298 \mathrm{~K}$ & 75 \\
\hline \multirow{2}{*}{ Zeolite $13 \mathrm{X}$} & \multirow{2}{*}{37.2} & 7.4 & 32 bar, $298 \mathrm{~K}$ & \multirow[b]{2}{*}{76} \\
\hline & & 3.3 & 1 bar, $323 \mathrm{~K}$ & \\
\hline Zeolite $\mathrm{NaX}$ & 49.0 & 7.8 & 30 bar, $302 \mathrm{~K}$ & 77 \\
\hline \multirow{2}{*}{ AC-MAXSORB } & \multirow{2}{*}{16.2} & 25.0 & 35 bar, $298 \mathrm{~K}$ & \multirow{2}{*}{$\begin{array}{l}78 \\
79\end{array}$} \\
\hline & & 2.1 & 1 bar, $301 \mathrm{~K}$ & \\
\hline AC-Norit R1 & 22.0 & 10 & 30 bar, $298 \mathrm{~K}$ & 77 \\
\hline AC-Norit RB2 & - & 9.5 & 40 bar, $298 \mathrm{~K}$ & 32 \\
\hline \multirow{3}{*}{ BPL carbon } & \multirow{3}{*}{23.3} & 8.4 & 55 bar, $298 \mathrm{~K}$ & 32 \\
\hline & & 1.9 & 1 bar, $298 \mathrm{~K}$ & 67 \\
\hline & & 1.9 & 1 bar, $301 \mathrm{~K}$ & 79 \\
\hline
\end{tabular}




\begin{tabular}{ccccc}
\hline COF-102 & - & 27.3 & 55 bar, 298 K & ${ }^{32}$ \\
\hline MOF-177 & 35.0 & 32.5 & 30 bar, 298 K & 35 \\
& & 20.0 & 15 bar, 298 K & 74 \\
\hline MOF-5 & 34.1 & 1.9 & 1 bar, 298 K & 76 \\
(IRMOF-1) $^{*}$ MCM-48 $^{\text {c }}$ & - & 21.7 & 35 bar, 298 K & ${ }^{35}$ \\
\hline MIL-53(Al, Cr) $^{\text {d }}$ & 36.0 & 0.8 & 1 bar, 298 K & ${ }^{80}$ \\
\hline MIL-47(V) $^{\text {d }}$ & - & 10 & 25 bar, 302 K & 77 \\
\hline PAF-1 & - & 11 & 20 bar, 302 K & ${ }^{7}$ \\
\hline
\end{tabular}

${ }^{\mathrm{a}}$ Three dimensional pillared-layer-metal organic framework; ${ }^{\mathrm{b}}$ Amine functionalized MOF; ${ }^{\mathrm{c}} \mathrm{A}$ type of amine-attached silica; ${ }^{\mathrm{d}} \mathrm{MIL}=$ Materials of Institut Lavoisier, (mesoporous MOFs);

${ }^{\mathrm{e}}$ Microporous polyphenylene network

Selective adsorption of $\mathrm{CO}_{2}$ on micro/mesoporous inorganic and organic adsorbents such as zeolites, silica gels, aluminas and activated carbons is used commercially for the separation of bulk $\mathrm{CO}_{2}$ from a gas mixture and removal of trace $\mathrm{CO}_{2}$ from a contaminated gas. Selective adsorption of $\mathrm{CO}_{2}$ over gases like $\mathrm{CO}, \mathrm{CH}_{4}, \mathrm{~N}_{2}$, $\mathrm{O}_{2}$ and $\mathrm{H}_{2}$ by these materials is caused by van der Waals attraction between the $\mathrm{CO}_{2}$ molecule and the adsorbent surface as well as by the pole-pole and pole-ion interactions between the permanent quadrupole of the $\mathrm{CO}_{2}$ molecules and the polar and ionic sites of the adsorbent surface. The varied morphology and surface chemistry of these physisorbents give rise to strikingly different characteristics for sorption of $\mathrm{CO}_{2}$ as a pure gas or as a gas mixture. These materials show different adsorption capacities of $\mathrm{CO}_{2}$ at a given gas pressure and temperature. In addition, the low to moderate isosteric heats of adsorption of these adsorbents permit reversible adsorption of $\mathrm{CO}_{2}$ and relatively easier desorption of $\mathrm{CO}_{2}$ from these materials. In particular, zeolites exhibit extremely high capacity for $\mathrm{CO}_{2}$ at a very low pressure because of the very strong quadrupole-ion interaction. Physical adsorption of $\mathrm{CO}_{2}$ by microporous zeolite $13 \mathrm{X}$ has been reported to provide high $\mathrm{CO}_{2}$ adsorption capacity at ambient temperature, but there is a relatively high energy requirement for regeneration, especially in the presence of water $^{19}$.

Recently, a range of microporous crystalline zeolite analogues has been developed, in particular, metal-organic frameworks (MOFs), covalent organic frameworks (COFs) and zeolitic imidazolate frameworks (ZIFs) that exhibit exceptional uptakes and selectivity to $\mathrm{CO}_{2}$. MOFs and COFs present very large specific surface areas $\left(>3000 \mathrm{~m}^{2} \mathrm{~g}^{-1}{ }^{32}\right)$ but in some cases limited physicochemical stability. On the 
other hand, ZIFs present lower surface areas (up to $1700 \mathrm{~m}^{2} \mathrm{~g}^{-1}{ }^{67}$ ) but higher chemical stabilities. Several groups have reported MOFs that have high $\mathrm{CO}_{2}$ adsorption capacity at ambient temperature under dry conditions $35,75,77$.

Amorphous microporous organic polymers have received recent interest in gas storage applications ${ }^{40,56,82,83}$. They present surface areas up to $1900 \mathrm{~m}^{2} \mathrm{~g}^{-1} 40$ with the exception of the recently reported PAF-1 that exhibits a BET surface area $>5000 \mathrm{~m}^{2} \mathrm{~g}^{-1}$ ${ }^{84}$. Capture capacities at atmospheric pressure and room temperature of the tested HCPs are similar to other carbon-based adsorbents, like commercial activated carbons ${ }^{79,} 67$, higher than some MOFs ${ }^{74,76}$ and lower than zeolite $13 \mathrm{X}^{76}$ and amine-functionalized $\mathrm{MOFs}^{75}$. At higher pressures ( 30 bar) these HCPs reached capture capacities superior to zeolite-based adsorbents ${ }^{19,77}$ and activated carbons ${ }^{77}$ but inferior to PAF-1 ${ }^{84}$, and the highest surface area MOFs and COFs. However, taking into account the low isosteric heat of $\mathrm{CO}_{2}$ adsorption and the selectivity towards $\mathrm{CO}_{2}$ of these HCPS, they may be suitable candidates for pre-combustion capture applications where high $\mathrm{CO}_{2}$ partial pressures are involved.

\section{Conclusions}

A series of hypercrosslinked polymers has been characterized and tested for $\mathrm{CO}_{2}$ capture. HCPs synthesized using DCE as solvent presented suitable microporosity development for $\mathrm{CO}_{2}$ adsorption purposes. However, use of cyclohexane, $n$-hexane and dodecane as solvents resulted in negligible textural development. $\mathrm{CO}_{2}$ capture capacities where evaluated in pure $\mathrm{CO}_{2}$ under atmospheric and high pressures and room temperature. Maximum $\mathrm{CO}_{2}$ uptakes of up to $13.4 \mathrm{mmol} \mathrm{g}^{-1}(59 \mathrm{wt} \%)$ at $298 \mathrm{~K}$ and 30 bar were reached.

$\mathrm{CO}_{2}$ capture capacities of the HCPs are comparable to those of high-surface area adsorbents found in the literature. In addition, these polymers are relatively inexpensive and present low isosteric heats of $\mathrm{CO}_{2}$ adsorption and good selectivity towards $\mathrm{CO}_{2}$. Thus, HCPs synthesized in this work show promising characteristics to be applied in pre-combustion $\mathrm{CO}_{2}$ capture processes by means of PSA cycles. 


\section{Acknowledgements}

We are grateful for funding to EPSRC via EP/G061785/1 and to MICINN via Project ENE2008-05087. C.F.M. is grateful to the CSIC JAE-Predoc Program, co-financed by the European Social Fund, for funding a short stay at the Department of Chemistry, University of Liverpool. A.I.C. is a Royal Society Wolfson Merit Award holder.

\section{References}

1. J. D. Figueroa, T. Fout, S. Plasynski, H. Mcllvried and R. D. Srivastava, Int. J. Greenh. Gas Control, 2008, 2, 9-20.

2. A. D. Ebner and J. A. Ritter, Separation Science and Technology, 2009, 44, 1273-1421.

3. G. P. Knowles, J. V. Graham, S. W. Delaney and A. L. Chaffee, Fuel Process. Technol., 2005, 86, 1435-1448.

4. M. L. Gray, Y. Soong, K. J. Champagne, J. Baltrus, R. W. Stevens Jr, P. Toochinda and S. S. C. Chuang, Sep. Purif. Technol., 2004, 35, 31-36.

5. X. Xu, C. Song, J. M. Andresen, B. G. Miller and A. W. Scaroni, Micro. Meso. Mat., 2003, 62, 29-45.

6. T. Filburn, J. J. Helble and R. A. Weiss, Ind. Eng. Chem. Res., 2005, 44, 1542-1546.

7. M. Radosz, X. Hu, K. Krutkramelis and Y. Shen, Ind. Eng. Chem. Res., 2008, 47, 37833794.

8. M. M. Maroto-Valer, Z. Tang and Y. Zhang, Fuel Process. Technol., 2005, 86, 14871502.

9. M. G. Plaza, C. Pevida, A. Arenillas, F. Rubiera and J. J. Pis, Fuel, 2007, 86, 22042212.

10. C. Lu, H. Bai, B. Wu, F. Su and J. F. Hwang, Energ. Fuel, 2008, 22, 3050-3056.

11. C. Pevida, M. G. Plaza, B. Arias, J. Fermoso, F. Rubiera and J. J. Pis, Appl. Surf.Sci., 2008, 254, 7165-7172.

12. M. G. Plaza, C. Pevida, B. Arias, M. D. Casal, C. F. Martín, J. Fermoso, F. Rubiera and J. J. Pis, J. Eng. - ASCE, 2009, 135, 426-432.

13. C. Pevida, T. C. Drage and C. E. Snape, Carbon, 2008, 46, 1464-1474.

14. T. C. Drage, J. M. Blackman, C. Pevida and C. E. Snape, Energ. Fuel, 2009, 23, $2790-$ 2796.

15. T. Nelson, L. Coleman, M. Anderson, J. Herr and M. Pavani, in Annual NETL $\mathrm{CO}_{2}$ capture technology for existing R\&D meeting, Pittsburgh, 2009.

17. J. Merel, M. Clausse and F. Meunier, Ind. Eng. Chem. Res., 2008, 47, 209-215.

18. D. Ko, R. Siriwardane and L. T. Biegler, Ind. Eng. Chem. Res., 2003, 42, 339-348.

19. S. Cavenati, C. A. Grande and A. E. Rodrigues, J. Chem. Eng. Data, 2004, 49, 10951101.

20. J. M. Martin-Martinez, R. Torregrosa-Macia and M. C. Mittelmeijer-Hazeleger, Fuel, 1995, 74, 111-114.

21. A. Vishnyakov, P. I. Ravikovitch and A. V. Neimark, Langmuir, 1999, 15, 8736-8742.

22. D. Cazorla-Amoros, J. Alcaniz-Monge and A. Linares-Solano, Langmuir, 1996, 12 , 2820-2824.

23. J. A. Ritter and A. D. Ebner, Sep. Sci. Technol., 2007, 42, 1123-1193.

24. J. Yang, C.-H. Lee and J.-W. Chang, Ind. Eng. Chem. Res., 1997, 36, 2789-2798.

25. C. Song, Catal. Today, 2006, 115, 2-32.

26. X. Xiaoding and J. A. Moulijn, Energ. Fuel, 1996, 10, 305-325.

27. J. F. Jenck, F. Agterberg and M. J. Droescher, Green Chem., 2004, 6, 544-556.

28. J. M. Austell, Exploration and Production: The Oil and Gas Review, 2005.

29. J. Schell, N. Casas and M. Mazzotti, Energy Procedia, 2009, 1, 655-660. 
30. P. Xiao, S. Wilson, G. Xiao, R. Singh and P. Webley, Energy Procedia, 2009, 1, 631638.

31. D. Britt, H. Furukawa, B. Wang, T. G. Glover and O. M. Yaghi, Proceedings of the National Academy of Sciences, 2009, 106, 20637-20640.

32. H. Furukawa and O. M. Yaghi, J. Am. Chem. Soc., 2009, 131, 8875-8883.

33. S. Choi, J. H. Drese and C. W. Jones, ChemSusChem, 2009, 2, 796-854.

34. H. Hayashi, A. P. Cote, H. Furukawa, M. O/'Keeffe and O. M. Yaghi, Nat. Mater., 2007, 6, 501-506.

35. A. R. Millward and O. M. Yaghi, J. Am. Chem. Soc., 2005, 127, 17998-17999.

36. J.-X. Jiang and A. I. Cooper, Topics Curr. Chem., 2009, 293, 1-33.

37. M. P. Tsyurupa and V. A. Davankov, React. Funct. Polym., 2002, 53, $193-203$.

38. M. P. Tsyurupa and V. A. Davankov, React. Funct. Polym., 2006, 66, 768-779.

39. V. A. Davankov and M. P. Tsyurupa, React. Polym., 1990, 13, 27-42.

40. C. D. Wood, B. Tan, A. Trewin, H. Niu, D. Bradshaw, M. J. Rosseinsky, Y. Z. Khimyak, N. L. Campbell, R. Kirk, E. Stockel and A. I. Cooper, Chem. Mater., 2007, 19, 20342048.

41. J. Y. Lee, C. D. Wood, D. Bradshaw, M. J. Rosseinsky and A. I. Cooper, Chem. Commun., 2006, 2670-2672.

42. N. B. McKeown, P. M. Budd, K. J. Msayib, B. S. Ghanem, H. J. Kingston, C. E. Tattershall, S. Makhseed, K. J. Reynolds and D. Fritsch, Chem. Eur. J., 2005, 11, 26102620.

43. N. B. McKeown and P. M. Budd, Chem. Soc. Rev., 2006, 35, 675-683.

44. J.-X. Jiang, F. Su, A. Trewin, C. D. Wood, N. L. Campbell, H. Niu, C. Dickinson, A. Y. Ganin, M. J. Rosseinsky, Y. Z. Khimyak and A. I. Cooper, Angew. Chem. Int. Ed., 2007, 46, 8574-8578.

45. E. Stöckel, X. F. Wu, A. Trewin, C. D. Wood, R. Clowes, N. L. Campbell, J. T. A. Jones, Y. Z. Khimyak, D. J. Adams and A. I. Cooper, Chem. Commun., 2009, 212-214.

46. R. Dawson, A. Laybourn, R. Clowes, Y. Z. Khimyak, D. J. Adams and A. I. Cooper, Macromol., 2009, 42, 8809-8816.

47. A. I. Cooper, Adv. Mater., 2009, 21, 1291-1295.

48. V. A. Davankov, S. V. Rogozhin and M. P. Tsyurupa, US Patent 3729457, 1971.

49. S. N. Sidorov, L. M. Bronstein, V. A. Davankov, M. P. Tsyurupa, S. P. Solodovnikov, P. M. Valetsky, E. A. Wilder and R. J. Spontak, Chem. Mater., 1999, 11, 3210-3215.

50. V. A. Davankov, A. V. Pastukhov and M. P. Tsyurupa, J. Polym. Sci. Part B: Pol. Phys., 2000, 38, $1553-1563$.

51. A. V. Pastukhov, M. P. Tsyurupa and V. A. Davankov, J. Polym. Sci. Part B: Poly. Phys., 1999, 37, 2324 - 2333.

52. J.-H. Ahn, J.-E. Jang, C.-G. Oh, S.-K. Ihm, J. Cortez and D. C. Sherrington, Macromol., 2006, 39, 627-632.

53. V. V. Podlesnyuk, J. Hradil and E. Králová, React. Funct. Polym., 1999, 42, 181-191.

54. A. Li, Q. Zhang, G. Zhang, J. Chen, Z. Fei and F. Liu, Chemosphere, 2002, 47, 981989.

55. N. A. Penner, P. N. Nesterenko, M. M. Ilyin, M. P. Tsyurupa and V. A. Davankov, Chromatographia, 1999, 50, 611-620.

56. A. Trewin, D. J. Willock and A. I. Cooper, J. Phys. Chem. C, 2008, 112, 20549-20559.

57. R. Dawson, A. Laybourn, Y. Z. Khimyak, D. J. Adams and A. I. Cooper. Macromol., 2010, 43, 8524-8530.

58. D. C. Sherrington. Chem. Comm., 1998, 21, 2275-2286.

59. M. M. Dubinin, Carbon, 1989, 27, 457-467.

60. J. P. Olivier, S. Koch, M. Jaroniec, M. Kruk, Characterization of porous solids $V$ Elsevier, Amsterdam, 2000.

61. F. Stoeckli and L. Ballerini, Fuel, 1991, 70, 557-559.

62. S. Brunauer, L. S. Deming, W. E. Deming and E. Teller, J. Am. Chem. Soc., 1940, 62, 1723-1732.

63. S. Sircar, Appl. Surf.Sci., 2005, 252, 647-653.

64. J. A. Dunne, R. Mariwala, M. Rao, S. Sircar, R. J. Gorte and A. L. Myers, Langmuir, 1996, 12, 5888-5895.

65. S. Sircar and D. V. Cao, Chem. Eng. Tech., 2002, 25, 945-948.

66. R. Babarao and J. Jiang, Langmuir, 2008, 24, 6270-6278. 
67. A. Phan, C. J. Doonan, F. J. Uribe-Romo, C. B. Knobler, M. O'keeffe and O. M. Yaghi, Accounts Chem. Res., 2010, 43, 58-67.

68. A. Demessence, D. M. D'Alessandro, M. L. Foo and J. R. Long, J. Am. Chem. Soc., 2009, 131, 8784-8786.

69. C. Knöfel, J. Descarpentries, A. Benzaouia, V. Zelenák, S. Mornet, P. L. Llewellyn and V. Hornebecq, Micro. Meso. Mat., 2007, 99, 79-85.

70. I. A. A. C. Esteves, M. S. S. Lopes, P. M. C. Nunes and J. P. B. Mota, Sep. Purif. Technol., 2008, 62, 281-296.

71. S.-C. Hsu, C. Lu, F. Su, W. Zeng and W. Chen, Chem. Eng. Sci., 2010, 65, 1354-1361.

72. R. V. Siriwardane, M.-S. Shen and E. P. Fisher, Energ. Fuel, 2005, 19, 1153-1159.

73. C. F. Martín, M. G. Plaza, J. J. Pis, F. Rubiera, C. Pevida and T. A. Centeno, Sep. Purif. Technol., 2010, 74, 225-229.

74. Z. Liang, M. Marshall and A. L. Chaffee, Micro. Meso. Mat., 2010, 132, 305-310.

75. B. Arstad, H. Fjellvåg, K. Kongshaug, O. Swang and R. Blom, Adsorption, 2008, 14, 755-762.

76. Z. Zhao, Z. Li and Y. S. Lin, Ind. Eng. Chem. Res., 2009, 48, 10015-10020.

77. P. L. Llewellyn, S. Bourrelly, C. Serre, A. Vimont, M. Daturi, L. Hamon, G. de Weireld, J.-S. Chang, D.-Y. Hong, Y. Kyu Hwang, S. Hwa Jhung and G. Férey, Langmuir, 2008, 24, 7245-7250.

78. S. Himeno, T. Komatsu and S. Fujita, J. Chem. Eng. Data, 2005, 50, 369-376.

79. K. B. Lee, M. G. Beaver, H. S. Caram and S. Sircar, Ind. Eng. Chem. Res., 2008, 47, 8048-8062.

80. S. Kim, J. Ida, V. V. Guliants and J. Y. S. Lin, J. Phys. Chem. B, 2005, 109, 6287-6293.

81. A. Trewin and A. I. Cooper, Angew. Chem. Int. Ed., 2010, 49, 1533-1535.

82. C. D. Wood, B. Tan, A. Trewin, F. Su, M. J. Rosseinsky, D. Bradshaw, Y. Sun, L. Zhou and A. I. Cooper, Adv. Mater., 2008, 20, 1916-1921.

83. N. B. McKeown, B. Gahnem, K. J. Msayib, P. M. Budd, C. E. Tattershall, K. Mahmood, S. Tan, D. Book, H. W. Langmi and A. Walton, Angew Chem In Ed, 2006, 45, 18041807.

84. T. Ben, H. Ren, S. Ma, D. Cao, J. Lan, X. Jing, W. Wang, J. Xu, F. Deng, J. Simmons, S. Qiu and G. Zhu, Angew. Chem., 2009, 121, 9621-9624. 